\title{
A bird in the lab
}

\author{
by Monica Harrington
}

SCIENTIFIC NAME

Coturnix japonica

TAXONOMY

PHYLUM: Chordata

CLASS: Aves

ORDER: Galliformes

FAMILY: Phasianidae
Many domesticated lines of quail were lost during World War II, and modern populations are largely derived from the few that remained. Japanese quail are small in size and easy to care for, they grow quickly and they are prolific egg-layers; as a result, they have been farmed in large quantities across the globe. These qualities are also desirable in laboratory species, and the Japanese quail is commonly used in several areas of scientific research ${ }^{2}$.

\section{Research résumé}

Interest in the Japanese quail as a research model grew rapidly after researchers first extolled its value in 1959 (ref. 3). C. japonica has since been involved in research on genetics, growth, development, nutrition, physiology, behavior and toxicology (particularly endocrine disruption $)^{4}$. Japanese quail have contributed to studies of such diverse phenomena as fetal alcohol exposure ${ }^{5}$, the effects of microgravity on embryonic development ${ }^{6}$ and behaviors associated with addiction to substances like nicotine ${ }^{7}$ and cocaine ${ }^{8}$.

In 2005 , researchers first created transgenic quail by using lentiviral vectors to achieve tissue-specific expression of green fluorescent protein ${ }^{9}$.

The availability of a transgenic avian model has proven useful in studies of embryonic development ${ }^{10}$, obesity ${ }^{11}$ and neurobiology ${ }^{12}$. The Japanese quail genome sequence, published in 2013 (ref. 13), enables more detailed genetic analysis that could identify additional applications of this species as a model organism.

\section{Domestication}

Records suggest that Japanese quail were domesticated from common quail as early as the 11th century and originally kept as songbirds ${ }^{1}$. In the early 1900s, quail were bred for eggs and meat.

1. Mills, A.D., Faure, J.M. \& Rault, P. The Japanese quail. in The UFAW Handbook on the Care and Management of Laboratory and Other Research Animals 7th edn. (ed. Poole, T.) (Blackwell Science, Ltd., Oxford, UK, 1999).

2. Huss, D., Poynter, G. \& Lansford, R. Japanese quail (Coturnix japonica) as a laboratory animal model. Lab Anim. (NY) 37, 513-519 (2008).

3. Padgett, C.S. \& Ivey, W.D. Coturnix quail as a laboratory research animal. Science 129, 267-268 (1959).

4. Institute of Laboratory Animal Resources. Coturnix (Coturnix coturnix japonica): Standards and Guidelines for the Breeding, Care, and Management of Laboratory Animals (National Academy of Sciences, Washington, DC, 1969).

5. Smith, S.M. The avian embryo in fetal alcohol research. in Alcohol: Methods and Protocols (Methods in Molecular Biology) (ed. Nagy, L.E.) (Humana, Totowa, NJ, 2008).

6. Barrett, J.E., Wells, D.C., Paulsen, A.Q. \& Conrad, G.W. Embryonic quail eye development in microgravity. J. Appl. Physiol. 88, 1614-1622 (2000).

7. Bolin, B.L., Cornett, H.L., Barnes, A.F., Gill, K.E. \& Akins, C.K. Nicotine induces a conditioned place preference in male Japanese quail (Coturnix japonica). Physiol. Behav. 107, 364-367 (2012).

8. Akins, C.K. \& Geary, E.H. Cocaine-induced behavioral sensitization and conditioning in male Japanese quail. Pharmacol. Biochem. Behav. 88, $432-437$ (2008).

9. Scott, B.B. \& Lois, C. Generation of tissue-specific transgenic birds with lentiviral vectors. Proc. Natl. Acad. Sci. USA 102, 16443-16447 (2005).

10. Lin, H.J., Mersmann, H. \& Ding, S.T. Establishment of a transgenic quail model and an ex vivo culture system of yolk sac membrane endodermal epithelium cell for studying functions of individual genes in avian embryonic development. FASEB J. 29, 754.8 (2015).

11. Shin, S., Choi, Y.M., Han, J.Y. \& Lee, K. Inhibition of lipolysis in the novel transgenic quail model overexpressing $\mathrm{G}_{0} / \mathrm{G}_{1}$ switch gene 2 in the adipose tissue during feed restriction. PLOS ONE 9, e100905 (2014).

12. Seidl, A.H. et al. Transgenic quail as a model for research in the avian nervous system: a comparative study of the auditory brainstem. $\mathbf{J}$. Comp. Neurol. $\mathbf{5 2 1 , 5 - 2 3}$ (2013).

13. Kawahara-Miki, R. et al. Next-generation sequencing reveals genomic features in the Japanese quail. Genomics 101, 345-353 (2013). 